International Journal of Canadian Studies

Revue internationale d'études canadiennes
INTERNATIONAL JOURNAL OF CANADIAN STUDIES

REVUE INTERNATIONALF D'ÉTUDES CANADIENNES

\title{
"The Ends of Canadian Studies: A Research Note from Taiwan”
}

\section{Guy Beauregard}

Numéro 39-40, 2009

Culture - Natures in Canada

Culture - natures au Canada

URI : https://id.erudit.org/iderudit/040837ar

DOI : https://doi.org/10.7202/040837ar

Aller au sommaire du numéro

Éditeur(s)

Conseil international d'études canadiennes

ISSN

1180-3991 (imprimé)

1923-5291 (numérique)

Découvrir la revue

Citer cette note

Beauregard, G. (2009). "The Ends of Canadian Studies: A Research Note from

Taiwan". International Journal of Canadian Studies / Revue internationale

d'études canadiennes, (39-40), 343-352. https://doi.org/10.7202/040837ar 


\section{Guy Beauregard}

\section{"The Ends of Canadian Studies: A Research Note from Taiwan"}

The purpose of this research note is to ask: What can Canadian studies do in Taiwan? My attempt to think through this question has emerged from ideas that were generated at the inaugural meetings of the Association for Canadian Studies in Taiwan held in March 2008. ${ }^{\prime}$ Following these meetings, we have an opportunity to explore the stakes involved in pushing forward critical work named as "Canadian studies" in Taiwan and elsewhere. As I attempt to do so, I want to state clearly that I do not view Canadian studies as some sort of finished object that scholars could then simply import and situate within our own critical projects. I instead take seriously John Wadland's astute characterization of Canadian studies as an "unfinished project" with an institutional history. And as we know, this history-which scholars typically trace back to the Massey-Lévesque Commission (1949-1951) - has had distinct international dimensions. According to an estimate made by the International Council for Canadian Studies (hereafter, the ICCS), there are around 7,000 researchers around the world working on topics related to Canada (Jaumain 60; Cavell 90); the ICCS estimates that these scholars are able to reach over 150,000 students through their teaching and seminars ("International Council for Canadian Studies"; Symons 37). What could it mean for us scholars working in Taiwan or elsewhere to imagine ourselves as part of this community?

Before I get into the substance of my argument, I want to address two points of view that I believe will not help us to understand what Canadian studies can do in Taiwan. The first point of view I want to address can be summarized as follows: "Scholars in Taiwan now have access to funding, often from the Canadian Trade Office in Taipei (that is, the CTOT), so let's do Canadian Studies." Let me be clear: in no way do I wish to belittle the importance of funding sources for Canadian studies research or scholarly events focused on Canada. Nor do I wish to underplay the pivotal role that the CTOT has played-and continues to play-in helping to enable this kind of work in Taiwan. ${ }^{2}$ The inaugural Canadian studies meetings in Taiwan, and the productive conversations that these meetings have generated, would not have been possible without this support, and for this we should be grateful. But while access to funding can help Canadian studies scholars in Taiwan and elsewhere to push forward with our individual and collective projects, it does not provide sufficient grounds for 
us to be able to explain how and why doing Canadian studies could matter; nor does it help us to clarify our future objectives as teachers or researchers. In this respect, I believe it is reasonable to say that if gaining access to this funding is the end of our work, then we should acknowledge that we are satisfied to be academic mercenaries-simply following the money.

The second point of view I would like to address here at the outset can be summarized as follows: "Scholars in Taiwan now have a chance to obtain some new information or new knowledge about Canada, so let's do Canadian studies." Once again, I want to underline that there is obviously nothing wrong with gaining new information or new knowledge, whether it relates to Canada or to any other topic or concern that is close to our hearts. It does not require a great deal of imagination to recognize that some of the most rewarding work we do as teachers and researchers involves exposing ourselves, our peers or our students to new ideas and new perspectives. And when I think about the dissemination, here in Taiwan, of new information or new knowledge about Canada, I immediately think of these kinds of. exposure: through visiting speakers and writers; through conferences and other scholarly meetings; through new texts or other research materials that are from or about Canada; through new courses we have designed and taught; and through the groundbreaking work done by our graduate students as they have researched and written about topics relating to Canada. I certainly do not want to underplay the significance of any of this important work. However I do wish to make a point here that may initially appear to be counter-intuitive but which in fact resides at the heart of my argument in this brief research note: gaining more information or knowledge about Canada does not provide sufficient grounds for understanding the potential significance of Canadian studies in Taiwan or elsewhere if this information or knowledge is simply understood as an end to our work. As I will discuss below, I instead want to encourage us to think about Canadian studies as a question of learning understood in a broader sense than simply acquiring new information or new knowledge about an imaginary object called "Canada."

If, as I have suggested so far, gaining access to funding and acquiring new information or knowledge about "Canada" are insufficient grounds to explore what Canadian studies can do in Taiwan, then how can we move forward? I believe that any attempt to answer this question needs to take seriously the distinct structural conditions in which Canadian studies has emerged in Taiwan. The first condition we need to acknowledge is that relatively few scholars working as faculty members in universities in Taiwan did their graduate work in Canadian studies or at universities in Canada. Now clearly these are not the same thing: it is certainly possible to do strong Canadian studies research at the graduate level without studying in Canada; and studying at a university in Canada in no way leads straightforwardly to producing strong Canadian studies research! But with 
a handful of exceptions, very few scholars working in Taiwan have had the chance to be trained, at the graduate level, as "Canadianists" understood in a narrow sense - even though we may have arrived at topics relating to Canada through various alternative routes. This situation has a history. According to the data compiled by the Ministry of Education in Taiwan, the number of students from the Republic of China studying in Canada plunged from a peak number of 164 students in 1966 to a mere 14 students in 1971, the year following the Trudeau government's switch in diplomatic relations from Taipei to Beijing in 1970 (Education Statistics, 1997 60). ${ }^{3}$ What makes this point especially notable is the fact that this historical moment coincides almost precisely with the establishment of the first major cluster of Canadian studies associations (in the US in 1971, in Canada in 1973, in the UK in 1975, and in France in 1976). It also coincides with the establishment in 1972 of the Symons Report, a major inquiry commenting on the state of Canadian studies in Canada and elsewhere. ${ }^{4}$ So while state representatives have, since that time, actively promoted educational exchange between Taiwan and Canada - and here we could note significant markers such as the Memoranda on Education signed in 2005 and again in 2007-I believe that our current situation nevertheless remains an outcome of this history. ${ }^{5}$

An additional structural condition we need to acknowledge, whether we are working in Taiwan or elsewhere, is the genuine difficulty of doing Canadian studies understood as an interdisciplinary project. While the exact configuration of any interdisciplinary academic work is obviously unsettled and open to contestation, I believe that it requires scholars, at minimum, to look beyond received forms of disciplinarity in order to ask: How can broader social and cultural concerns become legible through an imaginary object called "Canada"? And in what ways do received forms of disciplinarity enable, or foreclose, our potential forms of engagement with these concerns? With these questions in mind, I could not help but notice that while scholars have been able to organize the Association for Canadian Studies in Taiwan, our inaugural meetings in March 2008 split into two, with discussions of Canadian literature and film held at National Central University and a second meeting focused on aboriginal studies and political studies held at the Ministry of Foreign Affairs office in Taipei. One could point out here that there must be practical dimensions to this academic division of labour that could, in turn, help to focus our critical conversations in productive ways. And I hasten to add that in no way do I wish to discount the hard work of the conference organizers to get these two important meetings off the ground. But this early split nevertheless makes me wonder about the kinds of conversations we might be able to have about topics relating to Canada. What could be enabled if scholars from across the humanities and social sciences, as well as from law and policy studies, were part of a broader critical conversation? To be sure, this early split in our meetings here in Taiwan in no way forecloses the future conversations we 
may potentially have; nor does it invalidate the interdisciplinary commitments individual scholars may bring to these conversations as they are presently configured. Yet I wonder if this early split may ultimately impede rather than push forward our collective attempts to thicken our points of engagements with topics relating to Canada.

Despite these challenges (some of which are historical, some of which are tied to received forms of disciplinarity), scholars working in Taiwan are nevertheless the beneficiaries of much hard work. As I mentioned above, one key platform, the Association for Canadian Studies in Taiwan, is now in place; and, as one of its founding members, I want to emphasize the importance of gaining access to the ICCS as a key international platform to enable us to extend our networks of exchange outside of Taiwan. ${ }^{6}$ And while new platforms for exchange are being developed in other ways, notably through our participation in the Pacific Asia Network of Canadian Studies (PANCS), I sense that if we do not push forward to attempt to join the ICCS, we risk remaining (to rework Richard Cavell's sly observation) "world famous across Taiwan." Yet as we work here in Taiwan, we are fortunate to be able to use and extend existing institutional platforms. Akey example that was very much in evidence during the first of our inaugural meetings is film studies at National Central University (developed in large part through the energy of Wenchi Lin), an institutional site that has organized and hosted screenings and discussions of films from and about Canada, often with the generous support of the CTOT. At National Tsing Hua University, we have directed a large-scale library acquisition project funded by Taiwan's National Science Council on the topic of Empire and Overseas Literature, a project that has enabled the National Tsing Hua University library system to purchase and house, among other materials, substantial Canadian studies resources (including materials published by the ICCS) and to make these resources accessible to all researchers and students. We should also gladly acknowledge that scholars at many universities across Taiwan have created space for Canadian studies through the courses they have designed and taught, the materials they have brought into the classroom, the graduate students they have supervised, and the generosity with which they have hosted writers and scholars visiting from Canada and elsewhere. All this work indicates that, despite the structural challenges we face, there is considerable grounds for optimism about the prospects for future critical work. 
Given our current conjuncture, I want to return to the central question animating this research note: What can Canadian studies do in Taiwan? As I mentioned above, I want to encourage us, at this key moment following the establishment of the Association for Canadian Studies in Taiwan, to think of Canadian studies as a potentially generative site of learning. A discussion of this broad topic could, of course, go in many possible directions. But for the purpose of my argument, I want to put forward a brief reading of one cultural text: Julia Kwan's award-winning feature film Eve $\&$ the Fire Horse (for additional details, see "A note about the film" appended below). Kwan's film is interesting to think about in our current context because of the way it draws attention to pedagogical projects in various institutional sites, including but not limited to the primary school system and the Catholic Church in Canada. In my discussion of these sites, I want to investigate how Kwan's film draws our attention to what I call pedagogies of interruption: the acts of teaching and learning performed by young Chinese Canadian characters in Vancouver in the 1970s as they work within - and, in certain instances, interrupt - the structures of knowledge that were promulgated and institutionally mediated at that time.

One of the striking aspects of Kwan's film is its setting, particularly the careful attention to detail it brings to its representation of Vancouver in the mid-1970s. Students reciting the Lord's Prayer in school; Pop Shoppe soft drinks and shag rugs at home; patrons smoking in movie theatres; ubiquitous ponchos and plaid pants-all these small details steadily accumulate to represent, with impressive clarity, the specific practices of this time and place. And, for the Eng family, this time and place appears to be poised at a significant moment of transition: a grandmother's death and the upcoming birth of a son signal an upcoming generational shift. Yet, following a miscarriage, the birth of a son does not occur; and following Eve Eng's repeated sightings of her grandmother, the grandmother's funeral does not appear definite as a mark of closure. Pregnancies that do not lead to life; funerals that do not lead to death: Kwan's film represents markers of transition that appear to be unstable and unsettled.

The narrative action of Kwan's film focuses on its young protagonist, the eponymous Eve, who along with her sister Karena attempts to make sense of the changes happening around her as she works within, and moves across, various institutional sites. As Eve does so, she is repeatedly subjected to various forms of discipline to regulate her actions and the narratives she is authorized to tell. During a choir rehearsal, for example, Eve is told to stop moving around too much (she has adopted an AfricanAmerican style she viewed on television and is consequently disciplined by a nun to conform with the body motions of a normative Christian whiteness); and, during a Sunday school discussion, Eve is told that the 


\section{Figure 1. Eve's book report ${ }^{8}$}

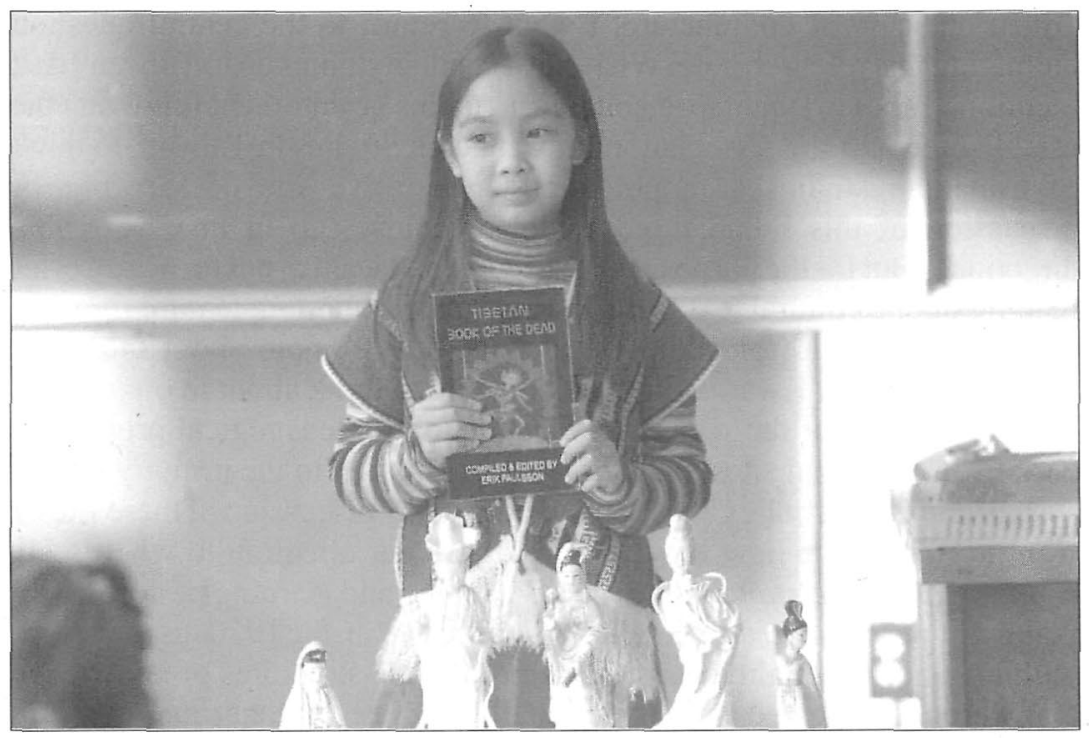

narrative she interjects about her father's miraculous escape from an accident in a stormy night in California is not acceptable in a pedagogical exercise dedicated to recalling Jesus's miracles! Yet despite these various forms of discipline, Eve consistently attracts an audience of her peers. In a schoolyard, she gathers her classmates to read out sensuous passages from "The Song of Solomon," signalling that, when she is handed a Bible, she is able to read it "against the grain." In this respect, Eve \& the Fire Horse represents the act of learning as a form of agency with parameters that are institutionally structured-yet with outcomes that are not fully determined.

To elaborate this point, I would like to draw attention to two short scenes in Kwan's film. The first scene, set in a primary school, focuses on Eve's enthusiastic book report about the Tibetan Book of the Dead, a report that Eve presents shortly following her grandmother's funeral. The semiotics of this scene are richly ironic: the white primary school teacher's response to Eve's report-in which she exclaims "Very good, Eve. Very exotic"-not only contrasts with Eve's classmates' responses (including the response of one classmate, Sally, who tells Eve that "[the] Goddesses [displayed by Eve during her book report] are cool"); it also encourages us to rethink the assumptions informing the six-step program the teacher has listed on the board (that is, a program to "prepare," "step up," "speak clearly," "share," and "respect"- concluding with a dryly ironic "thank you"). In this way, the institutional structure of the primary school as it is represented in Kwan's film lays out the specific pedagogical terms of white multicultural tolerance, notably by encouraging Eve to speak while also positioning her 


\section{Figure 2. Eve's and Karena's prayer}

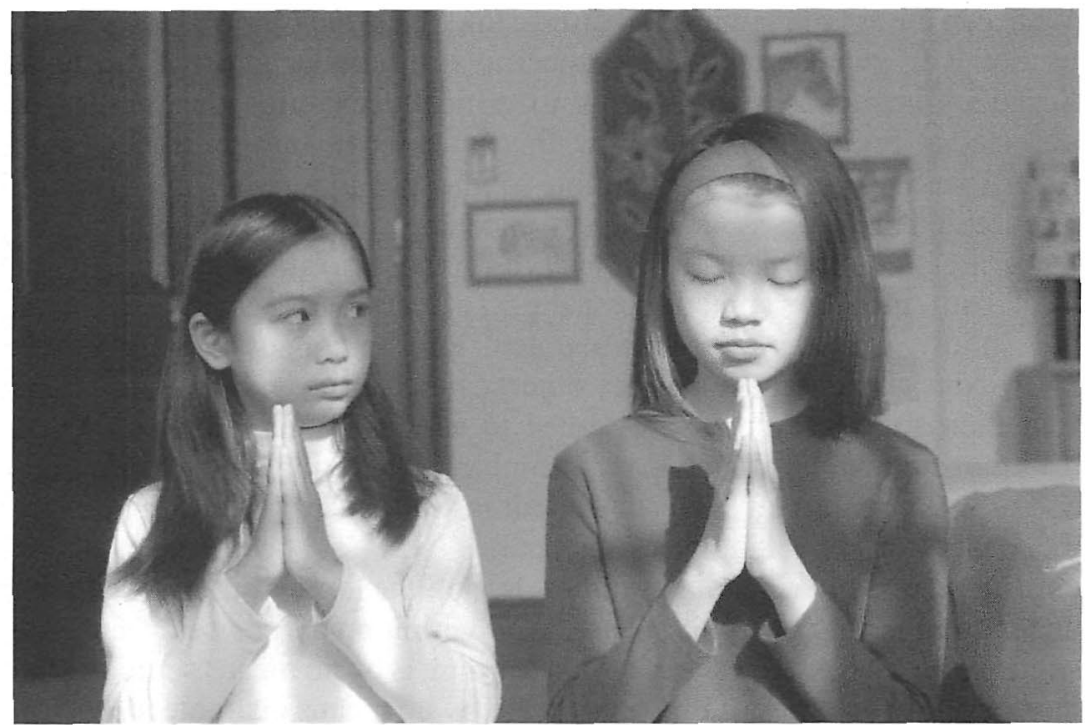

views as exotic and exogenous to Canada; but, at the same time, the teaching and learning that occurs in this scene-including the possible learning that we too might do as members of the audience-are in no way reducible to the ideological terms laid out by this institutional structure alone.

The second scene I wish to mention represents Eve's and Karena's first visit to a Sunday school — a visit that is part of the Eng family's decision to bring Christianity into their household. The film's representation of the Sunday school scene forcefully underlines the didacticism of the Catholic Church's pedagogical project (a project that is made immediately clear in the punchline of the song the children learn and sing: "The Bible tells me so"). Accordingly, as Eve moves from one site to another, she needs to adjust to the demands of different institutional modalities. Yet it's interesting to observe that while Eve's sister Karena can adjust smoothly to the institutional expectations of the church (she is the character who easily can say "yes" to the nun), Eve acts within and not within the church's institutional frame. This point is vividly represented in the film through its representation of Eve's line of sight: during the Sunday school scene, she consistently looks across and beyond the cinematic frame, suggesting that her line of sight cannot be readily restricted or fully disciplined in this institutional site. 
What can the act of viewing and discussing Eve \& the Fire Horse mean for us now? In representing these specific institutional sites of learning, Kwan's film opens space for us to critically examine the politics of knowledge production-and how this knowledge may be received or refashioned. By drawing attention to the pedagogies of interruption represented in Kwan's film, I hope to encourage us to stop and think about our critical commitments as learners in relation to the wider project of Canadian studies. As I noted above, the act of learning as I am using it here is not simply a matter of receiving new information or acquiring new knowledge about some imaginary object called "Canada." If we are to take Canadian studies seriously, we need to ask, as Roger Simon has in a different context, how our work can enable us to "rethink our assumptions and organizing frameworks, subject our institutions to critique, and found the bases for new thoughts and actions" (2). To be sure, an active engagement with Canadian studies is not the only route to learning understood in this particular sense. And within many possible Canadian studies frameworks, the shape of this learning is by no means settled-and the possible outcomes of this process are by no means guaranteed. Yet on the basis of recent developments that have taken place in Taiwan, I believe there's an opportunity here for us to ask how critical projects relating to Canada can enable us to question the adequacy of the organization of knowledge in and across the disciplines in which we work. This is not simply a matter of inserting "Canadian" materials into already established institutional frames; it instead is a matter of scrutinizing the adequacy of existing institutional arrangements and the openings that they may offer for future critical work. For many of us working in Taiwan, a turn to Canadian studies can offer us a chance to work, as Smaro Kamboureli has recently observed, "outside of the accustomed routes we have taken as scholars" (xv). Doing so has the potential to open up a space for new critical conversations, in Taiwan and elsewhere, to think through "the ends of Canadian studies": an unfinished set of critical practices that we might learn to rearticulate, refashion, extend, or interrupt.

\section{A note about the film}

Julia Kwan's feature film Eve \& the Fire Horse (2005) had its world premiere at the Toronto International Film Festival and its international premiere at the Sundance Film Festival. It tells the story of the Eng family living in the greater Vancouver area in the 1970s, with a particular focus on the rich and emotive experiences of its nine year old protagonist Eve. Kwan has noted that "the film is very much filtered through the eyes of a young girl" - and that "the sensory experience [of the film] is heightened as each new experience is seen through a child's purity of gaze" ("Eve \& the Fire Horse"). Intriguingly, the camera positioning attempts to reinforce this 
point of view. As Kwan has observed, "[i]n keeping with the perspective of a child, [the Director of Photography] Nicolas [Bolduc] often positioned the camera at the height of a child, stealing glimpses" "Eve \& the Fire Horse"). The film has played at over forty international film festivals and won numerous awards in Canada and elsewhere: an Audience Award at the Vancouver International Film Festival in 2005; a Special Jury Prize for World Cinema at the Sundance Film Festival in 2006; the Claude Jutra Award for Best Direction on a First Feature Film from the Canadian Genie Awards in 2007; and the Lieutenant Governor's Daryl Duke Screenwriting Award in 2007. Additional details about the film are available at $\mathrm{http}: / / \mathrm{www}$.eveandthefirehorse.com/.

\section{Acknowledgements}

An earlier version of this paper was presented to members of the Association for Canadian Studies in Taiwan at National Central University on 8 March 2008. I wish to thank audience members at this important event for their questions and comments and commitment to the project of Canadian studies. Financial support from the National Science Council in Taiwan (NSC 97-2918-I-007-008 and NSC 97-2629-H-007-013-MY3) and institutional support from the Ontario Institute for Studies in Education at the University of Toronto helped me to complete this manuscript and is gratefully acknowledged.

\section{Notes}

1. The first meeting, entitled "A Nation in Between: A Conference on Canadian Literature and Cinema," was held at National Central University, Taiwan, on 8 March 2008. The second meeting, on the topic of "Canadian Aboriginals and Land," was held at the Ministry of Foreign Affairs Foreign Service Institute, Taiwan, on 9 March 2008. I will have more to say about the significance of these two meetings later.

2. The Canadian Trade Office in Taipei has disseminated funding for academic work relating to Canada in a variety of ways, notably through the Canadian Studies Scholarship Program, but also by providing support for academic conferences, lecture tours, seminars, and library acquisitions. A summary of the forms of support that are currently available can be found on the CTOT website posted at: http://www.canada.org.tw/.

3. Perhaps more significantly, the official number of students from Taiwan studying in Canada remained low throughout the 1970s and most of the 1980s, dropping down to a mere 9 students in 1984 and 1985 (Education Statistics, 1990 60). Student numbers jumped dramatically shortly after the lifting of martial law in Taiwan in 1987: while only 15 students from Taiwan studied in Canada in 1988, the figure jumped to 1201 students in 1989 , climbing to a peak of 3031 students in 1996 (Education Statistics, 2004 66).

4. The first two volumes of the Symons Report were published in 1975. Of particular interest here is the extended discussion, in Volume II, of "Canadian Studies Abroad." In a section on the People's Republic of China, the Report notes the August 1972 academic exchange agreement between Canada and the 
PRC, providing an official commitment-however modest-for students and faculty to move between these two countries. Taiwan is unnamed in the Symons Report, accurately indicating the zero-sum logic of realpolitik during this era. For a discussion of this historical moment, with attention to its international implications, see Jaumain 15-17.

5. The objectives of these Memoranda on Education are listed on Taiwan's Ministry of Education website at www://english.moll.gov.tw/; follow the links to "Education Categories," "Cultural and Educational Exchange," and "MOE Signs a Memorandum on Exchange with Canada for the Second Time." The 2007 signing extended this bilateral agreement until 2010.

6. At the time of writing, the International Council for Canadian Studies consists of 21 national and multinational Canadian studies associations and 6 associate members representing, in sum, 39 countries. The Association for Canadian Studies in Taiwan is not yet a member.

7. Cavell foregrounds the phrase "world famous across Canada"- -adapted from the work of Canadian writer Mordecai Richler-in the title of his contribution to the recent collection Trans.Can.Lit in order to "[highlight] a critical crux that has plagued [Canadian] literature especially since its post-World War II period of development" (85). I have adapted Cavell's formulation, with gentle humour, to try to push forward our understanding of the stakes involved in doing Canadian studies here and now in Taiwan.

8. The images reproduced on pages 348 and 349 are from the film's website: www.eveandthefirehorse.com.

\section{Works Cited}

Cavell, Richard. "World Famous Across Canada, or TransNational Localities." Trans.Can.Lit: Resituating the Study of Canadian Literature. Ed. Smaro Kamboureli and Roy Miki. Waterloo, ON: Wilfrid Laurier UP, 2007. 85-92.

Education Statistics, The Republic of China. Taipei: Ministry of Education, 1997.

Education Statistics, The Republic of China. Taipei: Ministry of Education, 2004.

"Eve \& the Fire Horse: A Film by Julia Kwan." Press release. Available:

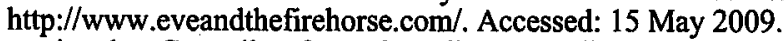

"International Council for Canadian Studies." Homepage. Available: http://www.iccs-ciec.ca/. Áccessed: 15 May 2009.

Jaumain, Serge. The Canadianists: The ICCS / 25 Years in the Service of Canadian Studies. Ottawa: International Council for Canadian Studies, 2006.

Kamboureli, Smaro. Preface. Trans.Can.Lit: Resituating the Study of Canadian Literature. Ed. Smaro Kamboureli and Roy Miki. Waterloo, ON: Wilfrid Laurier UP, 2007. Vii-xv.

Kwan, Julia, director. Eve \& the Fire Horse. 2005. Mongrel Media, 2006.

Simon, Roger I. The Touch of the Past: Remembrance, Learning, and Ethics. New York: Palgrave Macmillan, 2005.

Symons, T.H.B. "The State of Canadian Studies at the Year 2000: Some Observations." Journal of Canadian Studies 35.1 (2000): 27-51.

- To Know Ourselves: The Report of the Commission on Canadian Studies. Vol. I and II. Ottawa: Association of Universities and Colleges in Canada, 1975.

Wadland, John H. "Voices in Search of a Conversation: An Unfinished Project." Journal of Canadian Studies 35.1 (2000): 52-75. 